Effect of using co-ordination training on some special physical, physiological abilities, and numeric level for 110 meter / hurdles competitors 'Dr/ Mohamed Abd El-Mawgood El-sayed Abd El-all "Dr/ Hassan Ibrahim Abd El-Hamid Abou El-Magd

\title{
Introduction and research problem:-
}

Physical education has become with clear scientific nature depends on studies, researches and exploitation of interfusion among sciences by using more theories and information which aim at last to develop levels and physical achievements in all sports games.

So, Bastawysy Ahmed says (1997) that hurdles races require contestants with special qualities if they were anthropometric, physical and psychological qualities, If the contestant has these qualities, he will have control on technicality and this has a great positive affect on level progress at high levels sport field. (7: 92).
Hurdles jumping actually mean rhythm sprinting because it includes sprinting and jumping ten hurdles so, the correct rhythm is important for this mission success.

(15: 213).

In Eissam Abd Al khalek opinion (2005) co-ordination is considered public psychological and motor conditions for physical achievements from them the individual can have control on motor performance for all physical activities, motor coordination is considered one of complicated physical abilities which not appears at a solo image but it links with some coordination abilities (11:171).

Lu,D,J (2000) and Aissam Abd Al khalek (2005) agree that co-ordination abilities

"Assistant professor at department of track and field competition's applications and theories - faculty of physical Education for Boys Zagazig university.

" Lecturer at department of track and field competition's applications and theories - faculty of physical Education for Boys- Zagazig University.

Assiut Journal For Sport Science Arts 
originate from skillful performance requirements and they differ from each other in dynamic direction, coordination abilities don't appear as solo abilities but they always link co-ordinatedly (20: 67) ( 11:188)

Mechling add that coordination abilities may be seen from their complex system or motor direction or special contractive shape because all this aspects integrate at one frame on developing co-ordination abilities.( 21: 160)

Abo Al Aela Abd Al fatah (1997) refers to physical lifting is fundamental base to promote with physiological and physical level, and there is a reliable relation between physical lifiting and body systems reaction which result from exposure to different physical lifting and range of body musles and systems adaptation for these lifting.

\section{( $3: 43$ )}

Scientific knowledge for physical abilities is considered the needful entrance to develop athletes performance level, from now unexclusive training and physical abilities training exclusive training and physical abilities training exclusively don't depend only on trainer pre-experience or quantitative training but there is oneed of response on how and what and after that disposing and posing training programmes which work on developing and improvement (14: 19).

Dal monte, miri (1996) see, that physical activity is accompanied by a lot of processes and physical and physiological abilities which enable body to face physical effort requirements as well as, the individual regularity on training feeds to functional abilities at vital systems.( 8: 236).

Dal monte, miri (1996) see, that physical activity is accompanied by a lot of processes and physical and physiological abilities which enable body to face physical effort requirements as well as, the individual regularity on training feeds to functional abilities at vital systems.(8: 236).

This research problem from the two researchers experience and perm ant following for developing local and international records is the noticeable decrease at numeric level for 110 meter / hurdles race among Egyptian players compared with their consorts from foreign players the two researchers notice from enlightening , referential 
survey for all scientific reference at the referent ion frame borders for this research, also from nation net for information ( the internet) and meeting a lot of physical training professors and trainers that co-ordination abilities for 110 meter / hurdles players are very important for race achievement from start to end because player at start needs co-ordination among start, going, back expand and taking first steps to reach the first hurdle at utmost speed and the best case to take hurdle step which needs also full coordination between cutting and whirling feet and arms as well as. Player needs co-ordination abilities to take the distance among each hurdle at 3 steps and be on this rhythm among all hurdles and at the race end after jumping all hurdles the player nee co-ordination between taking last steps and ending race by pushing from chest at utmost speed and the power of all these coordinations is very important along race distance to achieve the best achievement.

Mohamed lofty AL sayed refers to co-ordination abilities importance because it is considered a condition for player achievement level so, if players have these for player achievement level so. If players have these abilities, they can company faster for motor performance, also good co-ordination level makes the player accept skillful variating so, developing co-ordination abilities reflects un exclusively on these aspects( motor performance quality, decreasing the intransitive time for iearning different artistic skills which link with specialistic activity quality motor performance quality and effectiveness, saving intransitive condition quality and effectiveness, saving intransitive condition to reach a good achievement level.( 24: 104).

So, the two researchers concentrated on posing a suggested training programme for developing Co-ordination abilities and knowing the effect of that on some physiological and physical abilities in a promotion attempt for numeric level for 110 meter / hurdles race among research sample.

\section{research objectives:-}

this research aims at posing a suggested training programme to develop co-ordination abilities and knowing its effect on some of physiological and physical abilities and numeric level for 110 meter / hurdles contestants from knowing about:

1- the suggest training programme effect on some of special physical abilities for 110 meter / hurdles contestants.

2- The suggest training programme effect on some of special physiological abilities for 110 meter / hurdles contestants. 
3- The suggested training programme effect on numeric level for 110 meter / hurdles contestants.

\section{research hypotheses:-}

for instructing work at research proce dwres and seeking to achieve its objectives the two researchers hypothesized that" 1- the suggested training programme has a positively effect on some special physical abilities for 110 meter / hurdles contestants.

2- The suggested training programme has a positively effect on some special physiological abilities for 110 meter / hurdles contestants.

3- The suggested training programme has appositive effect on numeric levels for $110 \mathrm{~m}$ contestants.

The used terms in the research:-

The ability of co-ordination

Gmal Ismael EL Nimky(2002) defined it as a collection of required qualities which should be found in player and related to physical, mental and rhythm aspects to perform the movement symmetrically and economize in exerting effort. (12:11).

\section{Anaerobic ability}

Mohammed Nasr al-Din Radwan, Khalid Bin Hamdan (2013) defined it as the ability to consistently keep violent muscle contractions that really depends on anaerobic mechanism processes in the energy supply. (26:123).

\section{Research procedures}

\section{Research method:}

The two researchers used the experimental methodizing to design both of premeasurements and post measurements for an experimental group to suit the nature of this search.

\section{Search sample:-}

the search sample was choosed deliberately among players of Zagazig university team for the years of $2013 \quad / 2014$ the number of the search sample individuals reached about (6)players addition to (5) players for the pilot experiment in the same search society.

Table (1)

The total homogeneity of search samples individuals in growth abilities ( $\mathbf{N}=\mathbf{1 1})$

\begin{tabular}{|c|c|c|c|c|c|c|}
\hline \multicolumn{2}{|c|}{ variables } & $\begin{array}{c}\text { Measurement } \\
\text { method }\end{array}$ & $\begin{array}{c}\text { Mathematical } \\
\text { means }\end{array}$ & $\begin{array}{c}\text { Standardized } \\
\text { deviation } \pm\end{array}$ & Median & $\begin{array}{c}\text { Skewness } \\
\text { Factor }\end{array}$ \\
\hline \multicolumn{2}{|l|}{ Age } & Year & $r \cdot . . \wedge$ & $\because v$. & $r . .$. & ס ס. \\
\hline \multicolumn{2}{|l|}{ Weight } & $\mathrm{Kg}$ & $79 . \leqslant 0$ & r.11 & $79 . \ldots$ & $.7 \leq$ \\
\hline
\end{tabular}




\begin{tabular}{l|l|l|l|l|l}
\hline \hline Length & $\mathrm{cm}$ & $1 \mathrm{9} .00$ & $1.9 \vee$ & $11 . .$. & $. .79-$ \\
\hline $\begin{array}{l}\text { Experimental } \\
\text { age }\end{array}$ & year & $\wedge .1 \leqslant$ &..$\vee \wedge$ & $1 .$. &. $.0 \mathrm{r}$ \\
\hline \hline
\end{tabular}

\section{Table (2)}

The search sample total homogeneity in physical, physiological abilities under searching $(\mathbf{N}=11)$

\begin{tabular}{|c|c|c|c|c|c|c|}
\hline \multicolumn{2}{|c|}{ variables } & Measurement & means & Standardized & Median & Skewness \\
\hline \multirow{6}{*}{ 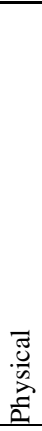 } & $\begin{array}{l}\text { Transition } \\
\text { speed }\end{array}$ & Second & r.o人 & $.1 r$ & $r .00$ &. .79 \\
\hline & $\begin{array}{l}\text { Legs muscle } \\
\text { strength }\end{array}$ & $\mathrm{Kg}$ & Y.0.TE & $1 . r q$ & $r .0 .$. & .11 \\
\hline & Flexibility & $\mathrm{cm}$ & rT.VV & r.r. & $r \varepsilon \ldots$ & $. r_{1}-$ \\
\hline & $\begin{array}{l}\text { Legs muscle } \\
\text { ability }\end{array}$ & M & $\leqslant .9$. & .11 & $\varepsilon . \wedge V$ &.$\vee \vee \wedge$ \\
\hline & $\begin{array}{l}\text { total Body } \\
\text { coordination }\end{array}$ & Second & $\wedge . \varepsilon$. & $.1 \mathrm{~V}$ & $\wedge . \leqslant \leqslant$ & $\cdot . \wedge \cdot-$ \\
\hline & $\begin{array}{l}\text { Motor - } \\
\text { balance }\end{array}$ & Degree & $7 \wedge .1 \mathrm{~V}$ & r.Yt & $\uparrow \wedge .$. &. .17 \\
\hline \multirow{4}{*}{ 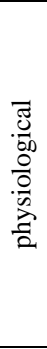 } & pulse & $\mathrm{N} /$ second & $10 \varepsilon . \wedge r$ & س. & $100 \ldots$ & $\cdot . \leqslant 1-$ \\
\hline & $\begin{array}{l}\text { anaerobic } \\
\text { ability }\end{array}$ & Watt & sov.ru & 9. ro & $\leqslant 09 . \ldots$ &. $.0 \mathrm{rr}$ \\
\hline & $\begin{array}{c}\text { Short } \\
\text { anaerobic } \\
\text { ability } \\
\end{array}$ & second & 0.74 & .11 & 0.05 & $1 . \leq 4$ \\
\hline & $\begin{array}{c}\text { Relative } \\
\text { horizontal } \\
\text { ability } \\
\end{array}$ & $\mathrm{Kg} / \mathrm{s}$ & דוא.r &. $.0 \mathrm{~V}$ & מז.r & .19 \\
\hline \multicolumn{2}{|c|}{$\begin{array}{c}\text { Numeric level for } 110 \\
\text { meter hurdles race }\end{array}$} & $\mathrm{N} / \mathrm{second}$ & 10.ru & . & $10 . \leqslant V$ & $1.1 \mathrm{~V}-$ \\
\hline
\end{tabular}

\section{Data collection tools:-}

The used tools and equipment for search abilities measurements.

- Restameir set to measure length. - Start examples.

- Standardized medical scales to - Flags, funnels, and measure weight

- Numeric stop watch

- Dinamometer set.

- Poles and rubber ropes organized signs

- Enoug hurdles.

- Athletics track about $400 \mathrm{~m}$ in length.

- Measurement ribbon to measure lengths, width, and out borders. physical, physiological abilities under being researched:- 
the two researchers carried out a referential survey on a group of specialized references, a number of previous studies group, revising information national web and sitting with

- physical abilities:-

- $\quad$ transformational speed

- $\quad$ Flexibility

- body total co-ordination

- physiological abilities:-

- pulse

- $\quad$ short anaerobic ability

The used Tests and Measurem
After acquaintance with studies which related to search topic and also a group of scientific references which specialized in tests and measurements and being with search targets, hypotheses and sample, the two researches got to definite a group of tests and measurement which its work to measure search variables and this is in the following:-

1- Measuring body weight (medical scales )/km.(27: 94).

2- Measuring body total length (AL Rastameter)/cm. (27: 61).

3- Measuring

transformational speed (sprinting test $30 \mathrm{~m}$ from motor start)/s0

(18: 247) sports training teachers and trainers to reach the most important significant physical, physiological abilities for 110 $\mathrm{m}$ hurdles contestants and they reached the following

- $\quad$ legs muscle strength

- $\quad$ legs muscle ability

- motor- balance $\begin{array}{ll}\text { - } & \text { anaerobic ability } \\ \text { - } & \text { relative horizantial ability }\end{array}$

$\begin{array}{ll}\text { - } & \text { anaerobic ability } \\ \text { relative horizantial ability }\end{array}$

nt in This research:-

4- $\quad$ Measuring legs muscle strength ( Dinamometer ) $/ \mathrm{kg}$. (27: 210)

5- $\quad$ Measuring Flexibility( informting legs sitting) $\mathrm{cm}$. (19: 281)

6- $\quad$ Measuring legs muscle ability (the distance of happing on the foot consecutive twice)/m. $(9: 129)$

7- Measuring body total co-ordination (numeric circle test ) /s (27: 329).

8- Measuring motorbalance (modified Bas test for Dinamic balance)/dgree.

(23: 326).

9- Measuring pulse $\mathrm{p} / \mathrm{m}$ (5:82)

10- measuring anaerobic ability, wat.(the total number of rotations of 30 seconds 
$\times 6 \mathrm{~m} \times$ specific power for test $. \mathrm{kg}) / 3$

and specific power estimated in kilograms is $4.50 \mathrm{~kg}$ according to Pilot Study and special protocol for Algometric bicycle which is held by the test. (26: 161-162).

11- Measuring short anaerobic ability /s. (sprinting test 60 yards) (26: 127-131).

12- Measuring relative horizantial ability $\mathrm{kg} / \mathrm{s}$. (weight/Time of Short anaerobic ability) (26: 128).

13- Measuring time $110 \mathrm{~m}$ hurdles /s and this according to the international / law for amateurs athletics games.

\section{Pilot Study:}

The two researchers carried out a pilot study in a period from Sunday 8 / 6 / 2014 to Saturday $14 / 6 / 2014$ on the pilot search sample and this study aimed at defining the following:-

1- The validity of tools and equipment used in measurement.

2- Difficulties which facing the application program. 3- Appropriate extent of training program for sample's abilities.

Suggested

training

programme.

Objective of programme. suggested training programme aims at developing coordination abilities(Body total coordination- Ultimate's strength - Balance - MotorRhythm - Motor-responses Muscle ability

Transformational speed Flexibility) to improve physiological and physical abilities and numeric level for 110 meter / Hurdles contestants.

Definition the period of application of training programme and the number of week units:-

Mofty Ibrahim Hamad (2001) said that direct preparation period for champion ships ranges between (5-8) weeks. (29: 72)

Mohamed Mersal Mohamed said that the number of training in one week to develop motor coordination ranges between (2-3) training ones. (25: 44).

Based on that the two searching did with Definition the period of open training programme Appliance with (8) weeks with (3) training ones in week.

qualities training for development coordination Abilities.

Abo El-Ela Abo Elfatah and Mohamed Mersal 
Mohamed agree that the qualities training for development coordination Abilities show in the next points:performance seventy ( 65 $100 \%$ ) from ultimate level for player.

the number of repeated times is based on performance seventy in every exercise as it ranges between (5-20) repeat.
And the number of training groups ranging between (3-6) group and the total comfort period is according to the severity of performance as it allows the body to return to normal situation. (3: 237-240) (25: 44) based on that two researchers defined the contents for training in suggested training programme in this research guided by these opinions.

table (3)

the training content for suggested training pro gramme by using coordinatied abilities exercises which applied on the search sample.

\begin{tabular}{|c|c|c|c|c|c|}
\hline \multirow{2}{*}{$\begin{array}{l}\text { Training } \\
\text { weeks }\end{array}$} & \multirow{2}{*}{ Training content } & \multicolumn{3}{|c|}{ Training ingredients contents } & \multirow{2}{*}{$\begin{array}{l}\text { The total } \\
\text { time for } \\
\text { training } \\
\text { units on } \\
\text { the } \\
\text { programme }\end{array}$} \\
\hline & & Severity & volume & density & \\
\hline First & $\begin{array}{l}\text { A group of exercises (special physical } \\
\text { preparing, coordinated exercises and psycho- } \\
\text { motor preparing) to suit muscle groups for } \\
\text { sample }\end{array}$ & $70-80 \%$ & $5-20 t$ & $\begin{array}{l}3-5 \\
\min \end{array}$ & $\begin{array}{l}120-150 \\
\min \end{array}$ \\
\hline Second & $\begin{array}{l}\text { A group of exercises (special physical preparing, } \\
\text { coordinated exercises and psycho-motor preparing } \\
\text { to suit muscle groups for sample. }\end{array}$ & $70-80 \%$ & $5-20 t$ & $\begin{array}{l}3-5 \\
\min \end{array}$ & $\begin{array}{l}120-150 \\
\min \end{array}$ \\
\hline Third & $\begin{array}{l}\text { Special physical preparing, coordinated } \\
\text { training addition to psycho-motor preparing } \\
\text { to improve working of muscles in } 110 \mathrm{~m} \\
\text { hurdles race. }\end{array}$ & $80-90 \%$ & $5-15 t$ & $\begin{array}{l}4-6 \\
\min \end{array}$ & $\begin{array}{l}120-150 \\
\min \end{array}$ \\
\hline Fourth & $\begin{array}{l}\text { Special physical preparing, coordinated } \\
\text { training addition to improve working of } \\
\text { muscles in } 110 \mathrm{~m} \text { hurdles race. }\end{array}$ & $80-90 \%$ & $5-15 t$ & $\begin{array}{l}4-6 \\
\min \end{array}$ & $\begin{array}{l}120-150 \\
\min \end{array}$ \\
\hline
\end{tabular}

Follow table (3)

the training content for suggested training pro gramme by using co-ordinatied abilities exercises which applied on the search sample.

\begin{tabular}{|c|c|c|c|c|}
\hline \multirow{2}{*}{$\begin{array}{l}\text { Training } \\
\text { weeks }\end{array}$} & \multirow{2}{*}{ Training content } & \multicolumn{2}{|c|}{$\begin{array}{l}\text { Training ingredients contents } \\
\end{array}$} & \multirow{2}{*}{$\begin{array}{lr}\text { The } & \text { total } \\
\text { time } & \text { for }\end{array}$} \\
\hline & & \begin{tabular}{l|l} 
Severity & volume \\
\end{tabular} & density & \\
\hline & Assiut Journal For Sport Science Arts & & & \\
\hline
\end{tabular}




\begin{tabular}{|c|c|c|c|c|c|}
\hline & & & & & $\begin{array}{l}\text { training } \\
\text { units on } \\
\text { the } \\
\text { programme }\end{array}$ \\
\hline Fifth & $\begin{array}{l}\text { A group of exercises for physical preparing } \\
\text { and coordinated exercises to improve } \\
\text { physical and physiological abilities under } \\
\text { searching for sample in addition to develop } \\
\text { the art level for } 110 \mathrm{~m} \text { hurdles race. }\end{array}$ & $80-90 \%$ & $6-12 t$ & $\begin{array}{l}4-8 \\
\min \end{array}$ & $\begin{array}{l}120-150 \\
\min \end{array}$ \\
\hline Sixth & $\begin{array}{l}\text { A group of exercises for special physical } \\
\text { preparing and coordinated exercises to } \\
\text { improve physiological and physical abilities } \\
\text { under searching for sample in addition to } \\
\text { psycho-motor preparing to develop art level } \\
\text { for } 110 \text { in hurdles race. }\end{array}$ & $\begin{array}{l}90- \\
100 \%\end{array}$ & $4-10 t$ & $\begin{array}{l}10-12 \\
\min \end{array}$ & $\begin{array}{l}120-150 \\
\min \end{array}$ \\
\hline Seventh & $\begin{array}{l}\text { A group of special prepared training and } \\
\text { psycho-motor exercises to rise the art } \\
\text { performance standard and exploiting all art } \\
\text { abilities from functional side of sample in } \\
\text { addition to a group of coordinated exercises } \\
\text { to improve the training case and develop } \\
\text { sample ticnic performance. }\end{array}$ & $\begin{array}{l}90- \\
100 \%\end{array}$ & $4-10 t$ & $\begin{array}{l}10-12 \\
\min \end{array}$ & $\begin{array}{l}120-150 \\
\min \end{array}$ \\
\hline eighth & $\begin{array}{l}\text { A group of exercises for special physical } \\
\text { preparing and coordinated exercises to } \\
\text { improve physiological and physical abilities } \\
\text { under searching for sample in addition to } \\
\text { psycho-motor preparing to develop art level } \\
\text { for } 110 \text { in hurdles race. }\end{array}$ & $70-80 \%$ & $6-12 t$ & $\begin{array}{l}4-8 \\
\min \end{array}$ & $\begin{array}{l}120-150 \\
\min \end{array}$ \\
\hline
\end{tabular}

\section{carrying out research experiment:-}

pre - measurements:-

pre-measurements was carried out research sample in zagazig university stadium in Wednesday and Thursday 18$19 / 6 / 2014$. measurement was happened for physical abilities for research and the numeric level was measured for player $110 \mathrm{M} / \mathrm{H}$, in the next day physiology abilities were measured with physical education for boys zagazig university.

Fundamental experiment.

suggest programme was applied to research sample under care the two searching From Monday 23/6/2014 to Saturday 16/8/2014, And they appreciated during programme application Isolation all abilities and effects which affect experiment results For simple numbers of research.

post - measurements:-

post measurement was carried out to research sample at zagazig university stadium 
in Wednesday and Thursday 20-21/8/2014. and measurement was happened for physical abilities for research and numeric level for player was measured $110 \mathrm{M} / \mathrm{H}$, in the next day physiology abilities was measured with physical efficiency at faculty of physical education for boys zagazig university and the two searching.

statistical treatments:-

viewing and Discussing the results. firstly :- results viewing:

( Table 4)

differences significant between per and post measurement in physical abilities for research $\mathrm{N}=6$

\begin{tabular}{|c|c|c|c|c|c|c|c|}
\hline \multirow[t]{2}{*}{ Variables } & \multirow[t]{2}{*}{$\begin{array}{c}\text { Measurement } \\
\text { unity }\end{array}$} & \multirow{2}{*}{$\begin{array}{c}\text { Mean } \\
\text { For Per } \\
\text { measurement }\end{array}$} & \multirow{2}{*}{$\begin{array}{c}\text { Mean } \\
\text { For Post } \\
\text { measurement }\end{array}$} & \multicolumn{2}{|c|}{$\begin{array}{c}\text { Media } \\
\text { ranks }\end{array}$} & \multirow{2}{*}{$\begin{array}{l}\text { Statistical } \\
\text { test } \mathrm{z} \\
\text { from } \\
\text { Wilcoxon }\end{array}$} & \multirow{2}{*}{$\begin{array}{c}\text { Possibility } \\
\text { Sig } \\
\text { (P- value) }\end{array}$} \\
\hline & & & & $(-)$ & $(+)$ & & \\
\hline $\begin{array}{l}\text { Transition } \\
\text { speed }\end{array}$ & Second & r.7. & $r . \leqslant r$ & r.o. & $\cdots$ & Y.Y. & $\ldots r V$ \\
\hline $\begin{array}{l}\text { Legs muscle } \\
\text { strength }\end{array}$ & $\mathrm{kg}$ & $r .9 .1 \mathrm{~V}$ & rr. & $\cdots$ & r.o. & r.r. & $\ldots$ rA \\
\hline Flexibility & $\mathrm{cm}$. & r. r r & 19.18 & r.o. & $\cdots$ & Y.Y. & $\ldots r V$ \\
\hline $\begin{array}{l}\text { Legs muscle } \\
\text { ability }\end{array}$ & $\mathrm{M}$ & $\leq . \wedge 7$ & $0 . .9$ & $\cdots$ & r.o. & Y.Y. & $\ldots r V$ \\
\hline $\begin{array}{l}\text { total Body } \\
\text { coordination }\end{array}$ & Second & $\Lambda . \leqslant 0$ & 8.79 & r.o. & $\cdots$ & r.r. & $\cdots+r A$ \\
\hline $\begin{array}{l}\text { Motor } \\
\text { balance }\end{array}$ & degree & $71 .$. & Ar.o. & $\cdots$ & r.o. & r.r. & $\ldots r \lambda$ \\
\hline
\end{tabular}

* Statistically significant at $0.05>$ Sig.(p.value)

Table (5)

Improvement percentage in physical abilities for research $N=6$

\begin{tabular}{c|c|c|c|c}
\hline \hline variables & Measurement & pre & post & Improvement \\
\hline \hline
\end{tabular}

Assiut Journal For Sport Science Arts 


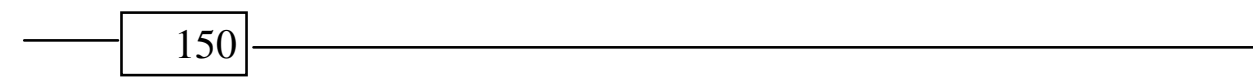

\begin{tabular}{|c|c|c|c|c|}
\hline & \multirow[t]{2}{*}{ unity. } & measurement & measurement & \multirow{2}{*}{ percentage $\%$} \\
\hline & & $\begin{array}{l}\text { Mathematical } \\
\text { mean }\end{array}$ & $\begin{array}{l}\text { Mathematical } \\
\text { mean }\end{array}$ & \\
\hline $\begin{array}{l}\text { Transition } \\
\text { speed }\end{array}$ & Second & r.T. & $r . \varepsilon r$ & $0 . . \varepsilon$ \\
\hline $\begin{array}{l}\text { Legs muscle } \\
\text { strength }\end{array}$ & $\mathrm{kg}$ & $\mathrm{r} .9 .1 \mathrm{~V}$ & מr.. & $0 . \mu \varepsilon$ \\
\hline Flexibility & $\mathrm{cm}$ & سMr & $19.1 \mathrm{~V}$ & $r \varepsilon . T \leq$ \\
\hline $\begin{array}{l}\text { Legs muscle } \\
\text { ability }\end{array}$ & M & $\varepsilon . \wedge \uparrow$ & 0.99 & $\varepsilon . V \mu$ \\
\hline $\begin{array}{l}\text { total Body } \\
\text { coordination }\end{array}$ & Second & $\wedge . \leqslant 0$ & 8.79 & $\wedge .9 r$ \\
\hline $\begin{array}{l}\text { Motor } \\
\text { balance }\end{array}$ & degree & $\uparrow \wedge . .$. & Nr.o. & rI.rr \\
\hline
\end{tabular}

\section{Table (6)}

differences significant between pre and post measurement in

physiological abilities for research $N=6$

\begin{tabular}{|c|c|c|c|c|c|c|c|}
\hline \multirow[t]{2}{*}{ Variables } & \multirow{2}{*}{$\begin{array}{c}\text { Measurement } \\
\text { unity }\end{array}$} & \multirow{2}{*}{$\begin{array}{c}\text { Mean } \\
\text { For Per } \\
\text { measurement }\end{array}$} & \multirow{2}{*}{$\begin{array}{c}\text { Mean } \\
\text { For Post } \\
\text { measurement }\end{array}$} & \multicolumn{2}{|c|}{$\begin{array}{c}\text { Media } \\
\text { ranks }\end{array}$} & \multirow{2}{*}{$\begin{array}{l}\text { Statistical } \\
\text { test } z \\
\text { from } \\
\text { Wilcoxon }\end{array}$} & \multirow{2}{*}{$\begin{array}{c}\text { Possibility } \\
\text { Sig } \\
\text { (P- value) }\end{array}$} \\
\hline & & & & $(-)$ & $(+)$ & & \\
\hline pulse & $\mathrm{N} / \mathrm{m}$ & 101.0. & T & r.o. & $\cdots$ & Y.M & $\ldots r V$ \\
\hline $\begin{array}{l}\text { anaerobic } \\
\text { ability }\end{array}$ & Watt & $\leqslant 0 \vee .0$. & $\leqslant \wedge 1.0$. & $\cdots$ & r.o. & r.ru & ד \\
\hline $\begin{array}{l}\text { short } \\
\text { anaerobic } \\
\text { ability }\end{array}$ & Second & 0.70 & מ & r.o. & $\cdots$ & מז. & $\ldots r$. \\
\hline $\begin{array}{l}\text { Relative } \\
\text { horizontal } \\
\text { ability. }\end{array}$ & $\mathrm{kg} / \mathrm{second}$ & Ir.rq & Ir..r & $\cdots$ & r.o. & Y.r. & $\ldots r \lambda$ \\
\hline
\end{tabular}

* Statistically significant at $0.05>$ Sig.(p.value) 
Table (7)

Improvement percentage in physiology abilities and numeric level for research $N=6$

\begin{tabular}{|c|c|c|c|c|}
\hline \multirow{2}{*}{ variables } & \multirow{2}{*}{$\begin{array}{l}\text { Measurement } \\
\text { unity. }\end{array}$} & $\begin{array}{l}\text { pre } \\
\text { measurement }\end{array}$ & $\begin{array}{l}\text { post } \\
\text { measurement }\end{array}$ & \multirow{2}{*}{$\begin{array}{l}\text { Improvement } \\
\text { percentage }\end{array}$} \\
\hline & & $\begin{array}{l}\text { Mathematical } \\
\text { mean }\end{array}$ & $\begin{array}{l}\text { Mathematical } \\
\text { mean }\end{array}$ & \\
\hline pulse & $\mathrm{N} / \mathrm{m}$ & $10 \wedge .0$ & سח. & 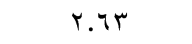 \\
\hline anaerobic ability & Watt & $\leqslant 0 V .0$. & $\leqslant \wedge 1.0$. & 0. ro \\
\hline short anaerobic ability & Second & 0.70 & سח 0.0 & 0.71 \\
\hline $\begin{array}{l}\text { Relative horizontal } \\
\text { ability. }\end{array}$ & $\mathrm{kg} / \mathrm{sec}$ ond & IY.Yq & it.. & $0.9 r$ \\
\hline
\end{tabular}

Table (8)

Differences significant between pre and post measurement in physiological abilities for research $N=6$

\begin{tabular}{|c|c|c|c|c|c|c|c|}
\hline \multirow{2}{*}{ Variables } & \multirow{2}{*}{$\begin{array}{c}\text { Measurement } \\
\text { unity }\end{array}$} & \multirow{2}{*}{$\begin{array}{c}\text { Mean } \\
\text { For Per } \\
\text { measurement }\end{array}$} & \multirow{2}{*}{$\begin{array}{c}\text { Mean } \\
\text { For Post } \\
\text { measurement }\end{array}$} & \multicolumn{2}{|c|}{$\begin{array}{c}\text { Media } \\
\text { ranks }\end{array}$} & \multirow{2}{*}{$\begin{array}{l}\text { Statistical } \\
\text { test } z \\
\text { from } \\
\text { Wilcoxon }\end{array}$} & \multirow{2}{*}{$\begin{array}{c}\text { Possibility } \\
\text { Sig } \\
\text { (P- value) }\end{array}$} \\
\hline & & & & $(-)$ & $(+)$ & & \\
\hline $\begin{array}{l}\text { Numeric } \\
\text { level to } \\
110 \\
\text { Meter } \\
\text { hurdles } \\
\text { race }\end{array}$ & Second & $10 . r \varepsilon$ & $1 \leq .9$. & r.o. & $\ldots$ & r.r. & $\cdot . r \wedge$ \\
\hline
\end{tabular}

* Statistically significant at 0.05>Sig.(p.value)

Table (9)

The percentage of improvement in numeric level under being researched $\mathrm{N}=6$

\begin{tabular}{|c|c|c|c|c|}
\hline \multirow{2}{*}{ variables } & \multirow{2}{*}{$\begin{array}{l}\text { Measurement } \\
\text { unity. }\end{array}$} & $\begin{array}{c}\text { pre } \\
\text { measurement }\end{array}$ & $\begin{array}{c}\text { post } \\
\text { measurement }\end{array}$ & \multirow{2}{*}{$\begin{array}{c}\text { Improvement } \\
\text { percentage }\end{array}$} \\
\hline & & $\begin{array}{c}\text { Mathematical } \\
\text { mean }\end{array}$ & $\begin{array}{c}\text { Mathematical } \\
\text { mean }\end{array}$ & \\
\hline $\begin{array}{l}\text { Numeric level to } \\
110 \quad \text { Meter } \\
\text { hurdles race }\end{array}$ & Second & $10 . r \varepsilon$ & $1 \leq .9$. & Y.AT \\
\hline
\end{tabular}

Second- result discussion.

Result discussion which through result viewing which verify the first hypothesis: researchers are reached and after statistical treatment to

Assiut Journal For Sport Science Arts 
post and pre measurement using non- parameters statistical way using (SPSS) Programme And After That Carrying Out The Mainly Experiment), Reached The Following:-

Table results number (4) and special for difference significance between pre and post measurement using Wilcoxon test in physical abilities for searching sample refer to have difference with statistically significance and good for post- measurement for searching sample where all values are $p$. value $<0.05$ in this variables for searching sample people.

Table results number (4) refer to degree means in physical abilities under $\mathrm{Be}$ researched between post and pre-measurement has improved all physical abilities for searching sample, the degree means in changes ( transition speed , flexibility total (coordination for body) all them decrease at compare degree means between post and pre measurement and in crease direction is in passive signs and this is an improvement signal, while the degree means in variables ( muscle ability for foot- movement balance- maximum power) all them increase at comparison degree means between post and pre measurement and increase direction is in positive signs and this is signal to improvement two researchers are returned this difference and statistically significance and improvement the means degree in passive and positive direction to effective a suggestion training programme using co ordination training leads to improve the physical abilities for researcher sample and this accept with the finding to it Both of (Ghada Abd ElHamid 1990) ( Amar meky 2012) ( Mohamed Esmat 2013) (lu,- D.J 2000) , all these researchers are reached for the coordination training leads to positive effect on the physical abilities which it 's the important element in improving numeric level to competitor $110 \mathrm{M}$ hurdles- for their researches samples.

Abo El Ela Ahmed (1997) refers to compatibility is considered one of the fundamental element to prepare sports to high levels where Harmonic performance featuring by easily movement and few errors with economic 
in effort and increase turnmotion.

\section{(3: 205)}

Mohamed sobhy (2003) refers to the importance of Harmonic in double movement which needs move more than one parts of the body parts at the same time and the importance will be double when all this parts move in a different direction) Harmonic needs fitness, balance, speed; kinetic sense, flexibility and accuracy the kinsetic motor performance and speed it. (27: 409).

Both of Moores,f (1996) Esam EL din Abd el khalek, (2005) assent the importance of co-ordinative abilities through reflection of its development for players as follows:-

1- improvement the quality of kinetic performance.

2- Learning Motor speed.

3- He ability to adapt mentalmotor programme to different circumstances for being carried out.

4- Effectively an a movement Beauty and flexibility. (28: 189) (13: 124)

Table Number (5) and special for improvement percentage in physical abilities for searching sample that find improvement percentage between pre and post measurement and good for to post measurement in physical abilities to 110 meter Hurdles competitor that improvement two researchers returned it to suggestion co-ordination programme using coordination training that apply on researchers sample.

Improvement percentages in physical abilities ranged between $24.34 \%$ as the Highest improvement percentages in flexibility variables and $4.73 \%$ as the least improvement percentage in muscle ability for foot variables ,two researchers returned it to positive effective to co-ordination training in Developing the physical abilities for 110 meter Hurdles competitors of research sample.

and this conclusion agree with another conclusion reach to it Both of ( Amar Meky 2012) (Raczek,2002) two researchers Reached that using coordination exercise lead to improvement the required physical abilities to prefect 110m Hurdles completion and this also do to improve the numeric level to 110 Hurdles race for their researchers sample. 
Through viewing in table (4) ,(5) verify the first by hypothesis that based on that suggestion training programme affect positively affected on physical abilities $110 \mathrm{~m}$ Hurdles competitors.

\section{Results discussion which} verify the second hypothesis:Table results number (6) and special for difference significance between pre and post measurement using Wilcoxon test in physiological abilities for researchers sample. Refer to find difference with statistically significance all physiological abilities between pre and post measurement for the sake of post test measurement for research sample where value range between ( $0.020: 0.028)$ and all them less than $<0.05$ in this variables for researchers sample.

Table results number (6) refer to degree means in physiological abilities under Be researched between pre and post measurement has improved in all physiological abilities for search sample, degree means in variables (pulse- maximum anaerobic ability) all them decrease at comparison degree means between pre and post measurement and the increase direction is on the passive signal direction and this is an improvement signal, while the degree means in variables (anaerobic ability - relative horizontal Ability) all of them increases at comparison degree means between post and pre measurement and increase direction is in positive signal direction and this is an improvement signal.

Two researchers are returned this difference and statistical significance and improvement the degree means in passive and positive direction to effective suggestion training programme using co-ordination exercises and Appling it on researchers sample during performing the mainly experiment, the coordination training leas to improve the physiological abilities for researchers sample.

and this agree with finding to it Both of (Ahmed farouk,2010) (gaser Abd El Rahman,2007) ( Abd El khalek ,2014) all those researchers are reached the training coordination leads to positive effective on physiological abilities which contributes in improvement the numeric level 
to $110 \mathrm{~m}$ Hurdles competitors for searching samples.

Dal- monte- mirri (1996) see the physical Activity attached by many operation and physiological and physical abilities which body can face physical effort requirements The person uniformity in training leads to make functional variables in vital equipment ( $8: 236$ ) .

table number (7) and special for improvement percentage in physiological abilities for searching sample shows the improvement percentage between pre and post measurement and good for post - measurement in all physiological abilities to $110 \mathrm{~m}$ Hurdles competitors this improve me two researchers return it to effective suggestion training programme using Coordination training that applies on researchers samples.

Improvement percentage in physiological range between $5.92 \%$ as the highest improvement percent in Ability horizontal relative variable and $2.63 \%$ as the least improvement percent in pulse variable, the two researchers attributed this improvement to the positive impact far Co- ordination exercises among $110 \mathrm{~m}$ Hurdles contestants.

This is consistent with the finding the both of (Ahmed farouk Ahmed, 2010), ( Yasser Abden Suleiman, 2007), these researchers concluded that using of co-ordination exercises to perfect $110 \mathrm{~m}$ hurdles competition which leads to an improvement numerical level of $110 \mathrm{~m}$ hurdles competitors for members of their research samples.

From showing in two tables (6), (7) the second hypothesis verify which provides for " the proposed training programme has positively effects on physiological abilities for $110 \mathrm{~m}$ hurdles players".

\section{Discussing the results of third hypothesis:-}

The results of table number (8) of differences significant between two measurements pre and post by using the test of Wilcoxon in numerical level of $110 \mathrm{~m}$ race for members of research samples referred to differences have statistical significant in numerical level of $110 \mathrm{~m}$ hurdles competitors between two measurements pre and post for the benefit of postmeasurement has value, 0.28 
that is less than < 0.05 for members of research sample.

Also, the result of the table (8) referred to means of degrees of pre - measurement and post -measurement became good in numerical level for $110 \mathrm{~m}$ hurdles competitors of research sample, where means of degrees least during comparison means of degrees between two measurement pre and post and the increasing direction is in negative signs direction and this is index for improvement.

Two researchers attributed these differences, statistical significant and mean of degrees improvement in negative direction to proposed training programme affection by using co-ordination exercise which was applied on members of research sample during fundamental experience, coordination exercises led to improvement the numerical level of $110 \mathrm{~m}$ hurdles players.

This is consistent with the finding the both of ( Ahmed farouk Ahmed ,2010), (Yasser Abden Suleiman 2007), ( Amar al-makki Ali al- Naegm,2012), ( Mohamed esmat AbdalGhany,2013), ( Abd al-khaliq Mohamed Abd al- khaliq
,2014), ( Reczek, 2002), all of these researchers Reach to that co-ordination exercises led to positive impact on numerical level of $110 \mathrm{~m}$ hurdles players for their research samples.

Bastawisi Ahmed (1997) say that $110 \mathrm{~m}$ hurdles race is one of the most enjoyable races hurdles and most difficult in performance where high hurdle reach to $106.7 \mathrm{~cm}$, its need to elasticity, grace full, compatibility and daring when clarifier hurdle, if it compare with other hurdles races for man or women. (7: 94)

And the table (9) of the improvement percent show that find improvement present between two measurements pre and post favor post measurement in numerical level of $110 \mathrm{~m}$ hurdles competitors, two researchers attributed this improvement to proposed training programme by using co-ordination exercises which were applied on members of research sample.

The improvement present in numerical level of $110 \mathrm{~m}$ hurdles players reached to 2.86 $\%$ two researchers attribute this to positive impact of coordination exercises in development the numerical 
Level for $110 \mathrm{~m}$ hurdles competitors of research sample.

This is consistent with finding the both of( Ahmed farouk Ahmed ,2010), (Yasser Abden Suleiman 2007), ( Amar al-makki Ali al- Naegm,2012), , where these researchers reach to the using of co-ordination exercises led to improvement the numerical level of $110 \mathrm{~m}$ hurdles competitors for members of their research samples.

Throw what has been presented in two tables (8), (9) the third hypothesis verify which provides for "the proposed training programme has positively affects on the numerical level of $110 \mathrm{~m}$ hurdles players".

Conclusions

and

\section{Recommendations:-}

First: conclusions:-

In the research sample limitations proposed training programme and the result which has been reached, the researchers conclude this:-

- the co-ordination exercises had appositive effect statistically significant on physical abilities (transformation Speedmaximum power- Legs muscle ability- Motor balance-
Flexibility- total Body coordination) for the members of research sample.

- The co-ordination exercises had appositive effect statistically significant on physiological abilities (anaerobic ability- horizontal relative- pulse- short anaerobic ability) under consideration for the members of research sample.

- The co-ordination exercises have appositive effect statistically significant on the numerical level of $110 \mathrm{~m}$ hurdles race for the member of research sample.

Second: recommendations:

In results, conclusion and the results which has been reached, the researchers recommend:

- the interest of co-ordination exercises have positive impact on physical abilities of $110 \mathrm{~m}$ hurdles competitors.

- The interest of co-ordination exercises have positive impact on physiological of $110 \mathrm{~m}$ hurdles competitors.

- The interest of co-ordination exercises have positive impact on the numerical level of 110 $m$ hurdles race.

- Guiding by values of quantities in this research which indicative physical and physiological abilities to doing 
likely researches in other competitions and on other sample

\section{References:}

1- Abdel Aziz elnemer, Nariman al-Khatib: physical preparation and training with weights junior. I1, professors of sports book, Cairo, 2000.

2- Abdel Khaliq Mohammed Abdel Khaliq: The effect of exercise on the interoperability capabilities of some physiological abilities and level numerical racers 400meter hurdles, unpublished $\mathrm{PhD}$ thesis, Faculty of Physical Education, Mansoura University, 2014.

3- Abu Ela Ahmed AbdelFattah: Sports Training (physiological foundations). 2nd Floor, Dar Al Arab Thought, Cairo, 1997.

\section{4- Ahmed Farooq Ahmed:}

The effect of the threshold distinguishing anaerobic exercises on some physiological abilities and the level of achievement numerical emerging 110 meters / hurdles. Unpublished Master Thesis, Faculty of Physical Education, Banha University, 2010.

5- Ali Mohammed galal alDin: Physiology of physical education and sports activities, 2nd edition, the Arab Center for Publishing, Zagazig.2003. 6- Ammar Makki Ali elnegm : relationship flexible torso and thighs completion of 110-meter hurdles, Qadisiyah Journal of Physical Education, Science Volume 12 Issue (1), 2012.

\section{7- Bastawisy}

Ahmed

Bastawisy: track and field competitions, the Arab Thought House, Cairo, 1997.

\section{8- Dal Monte, A. And Mirri}

G: The functional evaluation of the athlete state methods and of the art ، Medicine Della sport, 49th Turing 1996.

9- Donald chu : jumping into plyometric 100 exercises for power \& strength , human kinetics , London 1998.

10- El sayed Abdel Maksoud: theories of movement. Young Free Press, Port Said, 1986.

11- Essam El-Din Abdel Khaliq: Sports Training (theories - and applications). I 12, Knowledge facility, Alexandria, 2005.

\section{2- Gamal Ismail Alnmky:} physical preparation, second Part tree Durr library, Mansoura, 2002.

\section{3- Ghada Mohamed Abdel-}

Hamid: study to get to know some of the interoperability capabilities of the 100 meter 
hurdles and their relationship to the numerical level. Unpublished Master Thesis, Faculty of Physical Education, Tanta University, 1990.

\section{4- Hamdy Abdel-Rahim:} athletics, Specialized information for coaches Newstechnical bulletin-regional activities, No. 44, International Association of Athletics, Regional Development Center, Cairo, 2008.

15- Ibrahim Salem el sakar, Abdel Rahman Abdel Hamid Zaher, Ahmed Salim Hussein: Encyclopedia Physiology track competitions, book publishing center, the first edition, Cairo, 1998. .

\section{6- Johannes Rih Angborj}

Ritter: entrance to the theories and methods of the general training "synergy sports and technique." General German Institute of Physical Education, translating "Jurgen Falev", Leipzig, Germany Democracy, 1988.

\section{7- Julius}

Kasa., : Relationship of motor abilities and motor skills in sport Games "the Factors Determining Effectiveness in team games". Faculty of Physical Education and sport, Comenius University, Brat. Slava, Slovakia. 2005.

\section{8- Kamal}

Mohammed

Hassanein: fitness

components,
Abdel-Hamid, Sobhy

Thought, Cairo, 1997.

19- Leila elsayed Farhat: measurement and testing in physical education, 1st edition , Cairo, the center of the book for publication in 2001.

20- Lu, D, J : : Features and Classification Models of Movement coordination ability in track Field. Journal of Xi'an Ins Tiute of Physical Education, China. 2000.

21- Mechling, H.,:Coordinative Abilities. Chapter (7) in Psychology for physical Educators, By Auweele et al, Human Kinetic, Champaign, 1999.

\section{2- Mohammed}

Esmat Abdel Ghany: a training program to improve some harmonic capacity and its impact on the speed of the runners Breezing 100-meter hurdles junior, unpublished Master Thesis, Faculty of Physical Education for Girls, Alexandria University, 2013.

\section{3- Mohammad Hassan Allawi, Mohammed Nasr al- Din Radwan: motor performance tests, the Arab Thought House, Cairo, 2001.}


24- Mohamed Lotfy El sayed: athletic achievement and the rules of the training work. I 1, the center of the book for publication, 2006.

25- Mohamed

Mersal

Ahmed: basic principles in karate, Faculty of Physical Education for Boys, Mansoura University, 2004.

26- Mohammed Nasr al-Din Radwan, Khalid Bin Hamdan Al Masoud: physiological measurements in the field of sports, the center of the book for publication, 2013. 27- Mohammed

Subhy Hassanein: measurement and evaluation in physical education and sport, the Arab Thought House, c 2, $5^{\text {th }}$ edition, Cairo, 2003.

28- Moores,f: "education the deaf psychology . principles and a practice" , boston, Houghton, Mifflin, company, the education, 1996.

29- Mufti Ibrahim Hammad: Sports Coaching (planning application - leadership), 3rd edition, Dar Al Arab Thought, Cairo, 2001.

30- Raczek, J.: EntwicklungsVeränderungen der motorischen Leistungsfähigkeit der Schuljugend in drei Jahrzehnten (1965-1995).

Tendenzen, Ursachen und
Konsequenzen.

Sportwissenschaft 2002.

\section{1- Vladmir}

(32) 2 ,

Waldslaw Zumda, Zbigniew Witkowski : The Prognostic Value of Coordination Motor Ability "CMA" Indices in the Evaluation of Development of Soccer Players aged (16-19). Human Movement, Poland, 2001.

\section{2- Yasser Abdeen Soliman:}

The effect of anaerobic workouts on some blood and the level of digital players variables $110 \mathrm{~m}$ hurdles, published research, the Third International Scientific Conference, Faculty of Physical Education Girls Zagazig University, 2008. 